Policy Research Working Paper 1769

\section{Information, Incentives, and Commitment}

\section{An Empirical Analysis of Contracts between Government and State Enterprises}

Mary M. Shirley

L. Colin Xu

\section{WPS1769}

Written perfornance

contracts, wdely touted as a way to help stateowned enterpnises improve perfomance, seem to fail. Why? Because information asymmety lact of govemmen owmment. and lack of managral commitmentend to weak incentives and shirkig.

The World Bank

Policy Research Department

Finance and Private Sector Development Division May 1997 


\section{Summary findings}

Shirley and Xu analyze experience with written performance contraits between developing country governments and the managers of their state-owned enterprises. Such contracts have been a vogue since the mid-1980s, and substantial resources have been sunk into their design and entorcement, yet the few assessments to date show mixed results.

Using a simple agency model, they identify how problems of weak incentives stemming from information asymmetry, lack of government commitment, and lack of managerial commisment can lead to shirking.

They appiy the model to a sample of 12 contracts with monopoly enterprises in six developing countries (Gharia, India, the Republic of Korea, Mexico, the Philippines, and Senegal). All suffer from serious contracting problems. They find no pattern of improved perfurmance that can be attributed to the contracts.

Only three of the 12 case-study companies showed a turnaround in total factor productivity after contracts were introduced, six continued past trends, and three performed substantially worse under contracts than they had before. Labor productivity improved at a faster pace in four cases, and deteriorated in none, but the improvenent predated the contract.
Performance contracting assumes that government's objectives can be maximized, and performance improved, by setting targets that take into account the constraints placed on managers. For this to occur, the principals must be willing to explicitly stare their objectives, assign to them priorities and weights, translate them into performance improvement targets, provide incentives to meet those targets (or monitor the agents without incurring significant costs), and credibly signal their commitment to the contract. These conditions failed to materialize

Why would governments adopt contracts to which they were not conmitted or that were politically unrealistic? Sometimes because it enabled them to get foreign assistance.

How explain the managers' lack of commitment? Not surprisingly, managers with information advantages and bargaining power, and with no strong incentives or commitment from the government, used their advantages to manipulate the targets so as to ensure that their performance would be judged satisfactory.

Shirley and Xu outline the conditions under which performance contracts might succeed in improving performance.

This paper - a product of the Finance and Private Sector Development Division, Policy Research Department - is part of a larger effort in the department to analyze the role of institutions and incentives in public sector management, as well as in the private sector. The study was funded by the Bank's Research Support Budget under the research project "The Changing Role of the State" (RPO 678-69). Copies of this paper are available free from the World Bank, 1818 H Street NW, Washington, DC 20433. Please contact Paulina Sintim-Aboagye, room N9-030, telephone 202-473-8526, fax 202522 1155, Internet address psintimaboagye(a worldbank.org. May 1997. (48 pages)

\footnotetext{
The lolicy Research Working Paper Series disseminates the findings of work in progress to encourage the exchange of ideas about deveinpment wsues. An objective of the series is to get the findings out quickly, even if the presentations are less than fully polished. The papers carry the names of the authors and should be cited accordingly. The findings, interpretations, and conclusions expressed in this paper are entirely those of the authors. They do not necessarily represent the view of the World Bank, its Executive Directors, or the countries they represent.
} 
Information, Incentives and Commitment: An Empirical Analysis of Contracts between Government and State Enterprises ${ }^{1}$

by

Mary M. Shirley and L. Colin Xu

The authors are grateful for useful comments from Gerard Caprio, and for the contribution of Luke Haggarty, as well as the assistance of Zeny Kranzer, Bill Moore and Polly Means. The paper draws on work done by Mary Shirley for World Bank, Bureaucrats in Business: The Economics and Politics of Government Ownership, (Washington, D.C.: Oxford University Press, 1995) and the acknowledgements in that work apply here as well. 


\section{Introduction}

Written contracts between governments and state-owned enterprises (SOE) have enjoyed a vogue since the mid-1980s. Our survey of developing countries found 565 such contracts in 32 countries plus another 103,000 in China as of June, 1994 (table 1). We defined these contracts, which we termed performance contracts, as negotiated, written agreements between governments and the managers of their SOEs which specify explicit targets that SOE management pledges to achieve in a given time frame, and where performance is measured at the end of a specified period. ${ }^{1}$ Substantial resources have been sunk into the design and enforcement of these contracts, yet the few assessments to date show mixed results (see, for example, Shirley 1989, 1991; Nellis 1989; Trivedi 1990).

SOEs face more than the usual principal-agent problems. Typically, the agent (SOE management in this case) has more information than the principal (government) and can choose how much effort to expend. (For a review of the theoretical arguments see, Ross 1991; Stiglitz 1974; Sappington 1991.) The principal can only observe outcomes and cannot measure accurately the effort expended by the agent or distinguish the effects of effort from other factors affecting performance (Laffont and Tirole 1986). The assumption in much of the literature is that the principal is a residual claimant whose objective is to maximize his or her returns, and will monitor management effort accordingly. If there are multiple principals, they will share the same objective (although smaller stakeholders may try to free ride on the monitoring efforts of larger ones). If the 
shares of the enterprise are traded in a highly liquid stock market, the stockowners may choose to exit, in which case a large shareholder may take over the firm, oust the old manager and appoint a new, more capable one. The threat of such a takeover may act as a check on the behavior of incumbent managers.

SOEs, however, have no clear residual claimants; they are subject to multiple principals who impose multiple, often conflicting objectives and constraints on the enterprise (Jones, "The Linkage Between Objectives and Control Mechanisms in the Public Manufacturing Systems" in Trevedi, 1990). These multiple principals may derive benefits from objectives which run contrary to improving economic performance. For example, politicians may benefit politically from instructing SOEs to maximize employment (Shleifer and Vishny 1994). Bureaucrats might benefit from instructing SOEs to engage in activities that increase their power, prestige or perks (Buchannan et. al 1980). Besides the lack of a clear residual claimant, SOEs are often monopolies not subject to bankruptcy, and are also not vulnerable to takeover (Vickers and Yarrow 1988). As a result, it is especially difficult to judge managerial performance or to motivate managers to exert effort.

A written performance contract can be seen as a forcing mechanism to clarify objectives and make it easier to judge performance and motivate managers. The contract is negotiated between representatives of the multiple principals and the SOE, and translates the multiple goals into targets measured by specified criteria (Jones, "Performance Evaluation for State-Owned Enterprises" in Ramamurti and Vernon 1991). Targets can be weighted to reflect government priorities and provide further clarity. 
Management can be motivated to improve performance through bonuses based on achievement of the targets, while poor performance can be penalized through firing or demotion.

An implicit assumption underlying such contracts is that even as government's social or political objectives are being maximized, performance on economic measures can still be improved, by setting targets that allow for improvements within the constraints imposed by these noneconomic objectives. For example, even though a government requires a SOE to keep its labor force at current levels despite overstaffing, the company could still achieve contractual targets aimed at, for instance, improving quality or minimizing materials costs. Constraints are taken into account by selecting targets and/or criteria that measure only those factors which management can control. For instance, performance can be judged against past trends, rather than against some objective standard, to take account of factors which management can't change much from year to year. Thus, even if management can't reduce overstaffing they may still be able to improve the trend in labor productivity by expanding production through better use of plant and equipment. Or, to give another example, trends in profitability may be measured in constant prices to take account of management's inability to raise prices in real terms.

Drawing on the work of Sappington (1991), Lafont and Tirole (1987) and Willamson (1976 and 1985), ${ }^{2}$ we hypothesized that how well a contract does in improving SOE economic performance depends on how well it addresses three interrelated problems: information asymmetry, incentives, and commitment. Information 
problems arise because the contracting agents have different sets of information, and it may be costly to get information about whether the terms have been honored; thus each side can use the information it holds exclusively to improve its position at the expense of the other. At the same time, because not all contingencies can be fully anticipated and accounted for, it is impossible to design a contract that will cover all eventualities. To induce the contracting parties to comply with the contract's provisions, contracts include promises of incentives (rewards and penalties). But where information is imperfect and it is costly for government to pay the incentive, the reward may be set too low to motivate managers to improve performance. Since managers face a disutility of effort, under such low incentives they will shirk.

Each party must be convinced of the commitment of the other to honor the contract now and as circumstances change, but when government is one of the contracting parties it may be difficult or impossible to force government to comply. There may be no neutral third parties with the power to compel the government or its successors to meet its promises. Government in developing countries may face especially serious problems making credible commitments because the institutions (checks and balances, reputation, etc.) which curb arbitrary actions and bind successor administrations to the promises of their predecessors are weak (North and Weingast 1989; Levy and Spiller 1996). If managers believe that there is a high probability that government will renege on its commitments (such as the commitment to pay an incentive), they will not invest in learning or exert effort to improve results. Managerial commitment is also 
important. If managers are not committed to the contract, they may try to bargain that they are not punished regardless of the firm's performance.

The next section of this article presents a simple, agency theoretic model to illustrate how these contracting problems may affect performance. Section III examines how a sample of contracts dealt with each of the contracting problems and Section IV measures the success or failure of the contracts against objective, quantitative measures of firm performance. Section $V$ concludes with an assessment of the findings and the policy implications.

\section{The Model}

To illustrate how the problems of performance contracts affect SOE performance, we first develop a static model to show that, when enterprises have an information advantage the government will choose lower-powered incentives, which lead to an efficiency loss compared to when the government has complete information. Next we give two examples under a dynamic setup to show how the lack of commitment by either of the contracting parties can hurt SOE preformance. The theoretical arguments offered here emphasize the role of the manager in enterprise performance, and synthesize standard arguments of information economics in the context of SOE performance contracts.

\section{A. Information Asymmetry, Incentives and Performance: Static Analysis}


We make use of Freixas et al (1985) to compare the performance of an enterprise with and without an information advantage. ${ }^{3}$ Consider an enterprise which produces output $y$ of a product whose social value is $p$. The technology is characterized by (1) $y=e \theta$

where $e$ is managerial effort, and $\theta$ is the firm-specific efficiency level, beyond the control of the manager. Other inputs such as capital and labor are omitted based on the assumption that such inputs are observable to the government. By working hard the manager incurs disutility $\psi(e)$, with $\psi^{\prime}(e)>0$, and $\psi^{\prime \prime}(e)>0$

The government tries to motivate the manager using the following performance contract:

$$
R(y)=a+b y=a+b e \theta
$$

where $R$ is the reward to the manager: $a$ is the manager's base salary independent of the level of output and assumed to be positive, and $b$ represents the power of incentives. Linearity of the performance contract is assumed to simplify the analysis. ${ }^{4}$ In transferring $\$ 1$ to an enterprise, the government incurs costs of $\$(1+\lambda)$, where $\lambda$ is the additional costs associated with distortionary taxes and with administrating enterprises by bureaucrats (such as planning, monitoring, and verifying inputs and output). The manager maximizes his utility function,

$$
\pi^{F}=a+b e \theta-\psi(e)
$$

while the social welfare of the rest of the world is

$$
\pi^{o}=p e \theta-(1+\lambda)(a+b e \theta)
$$

So the objective function of a benevolent government is 


$$
W=p e \theta-\psi(e)-\lambda(a+b e \theta)
$$

\section{The Optimal Static Incentive Scheme under Complete Information}

There are two types of firms: firms with better technology $(\bar{\theta})$, and the others $(\underline{\theta})$. With complete information the government knows the type of an enterprise, and since it is costly to transfer funds to the enterprise, the government will maximize $W$ while making the manager's utility just equal to his or her reservation utility, which without loss of generality is assumed to be 0 . So the government hopes to solve the optimal incentive intensity $b$ from the following problem:

$$
\begin{aligned}
\text { Max } & =p e \theta-\psi(e)-\lambda(a+b e \theta) \\
& \equiv(1+\lambda)\left[\frac{p}{1+\lambda} e \theta-(a+b e \theta)\right]+(a+b e \theta-\psi(e)) \\
\text { s.t. } \quad a+b e \theta & =\psi(e) \\
\psi^{\prime}(e) & =b \theta
\end{aligned}
$$

The last equation is the rationality constraint -- the first order conditon for the manager to maximize $\pi^{F}$; the equation before the last one reflects the government's intention to leave no rent to the firm. Substituting the first constraint into the objective function, taking a derivative with respect to $b$, then substituting $\psi^{\prime}(e)=b \theta$, we get the optimal incentive intensity with perfect information:

$$
\text { (7) } \quad b^{*}=\frac{p}{1+\lambda} \equiv s
$$

The right hand, denoted as $s$, is the shadow price of output to the government: the government incurs a social cost of $\$(1+\lambda)$ to induce the enterprise to produce $\$ 1$ worth of output.

Static Incentive Scheme Under Incomplete Information 
Now suppose the enterprise manager has an information advantage. While the manager knows his or her enterprise's type ( $\bar{\theta}$ or $\underline{\theta}$ ), the government presumes that a firm's technology parameter is:

$$
\theta=\left\{\begin{array}{l}
\bar{\theta} \text { with probability }(1-v) \\
\underline{\theta} \text { with probability } v
\end{array}\right.
$$

Denote $\bar{e}(b), \underline{e}(b)$ as the utility-maximizing efforts when the bonus intensity is $b$ for firms with type $\bar{\theta}$ and $\underline{\theta}$. Since firms with better technology $(\bar{\theta}$ type $)$ have a higher marginal product, the first-order condition of the enterprise implies that $\bar{e}(b)>\underline{e}(b)$.

The maximization problem of the government now becomes

$$
\begin{aligned}
\max W & =v\{p \underline{\theta} \underline{e}(b)-\psi(\underline{e}(b))-\lambda[a+b \underline{\theta} \underline{e}(b)]\} \\
& +(1-v)\{p \bar{\theta} \bar{e}(b)-\psi(\bar{e}(b))-\lambda[a+b \bar{\theta} \bar{e}(b)]\}
\end{aligned}
$$

$$
\text { s.t } \begin{aligned}
\psi(\underline{e}(b)) & =a+b \underline{\theta} \underline{e}(b) \\
b \bar{\theta} & =\psi^{\prime}(\bar{e}) \\
b \underline{\theta} & =\psi^{\prime}(\underline{e})
\end{aligned}
$$

Constraint (9) says that the government will design a payment scheme so that the manager of an inefficient type will receive his or her reservation utility level and nothing more: the government hates to transfer any more than necessary to its SOEs since it costs the society an extra $\$ \lambda$. Constraint (10) implies that managers of both types of enterprise will maximize their utilities.

Substitute (9) and (10) into (8), we get

$$
W=v\{p \underline{\theta} \underline{e}(b)-(1+\lambda) \psi(\underline{e}(b))\}+(1-v)\{p \bar{\theta} \bar{e}(b)-\psi(\bar{e}(b))-\lambda \psi(\underline{e}(b))-\lambda b[\bar{\theta} \bar{e}(b)-\underline{\theta} \underline{e}(b)]\}
$$

Taking the derivative with respect to $b$ and setting it to zero, we get: ${ }^{5}$ 
(11) $s-b^{*}=\frac{\lambda}{1+\lambda}(1-v) \frac{\bar{\theta} \bar{e} \underline{\theta} \underline{e}}{v \underline{\underline{\theta}} \underline{e^{\prime}}(b)+(1-v) \bar{\theta} \overline{e^{\prime}}(b)}$

(11) implies that $b^{*}<s$. So when the firm's manager has an information advantage, the government will set a lower incentive than in the case of perfect information (in which $\left.b^{*}=s\right)$. Since $\bar{e}^{\prime}(b)>0$ and $\underline{e}^{\prime}(b)>0$, it follows that the performance of both types of firms will be lower under imperfect information than under perfect information.

\section{B. Commitment and Effectiveness of Performance Contracts}

The effectiveness of contracts depends not only on information and incentives but also on commitment. Although there are various ways in which lack of commitment is important to contracts, here we illustrate two types of lack of commitment: the government's commitment not to appropriate firm-specific investments of the manager; and the manager's commitment to stick to the terms of the performance contract. Expropriation Risks due to the Lack of Commitment by the Government

In this example the lack of commitment by the government reduces the returns of firm-specific investment and the manager's efforts. Consider a two-period setup: $t=0,1$. In period 0 , the manager sinks a firm-specific, non-contractible investment of $I$, which will improve output of period 1 by $K(I)$. The manager's investment can be viewed as his or her time spent on learning about the firm (its technology, personnel, and market), which is lost when he or she leaves the firm, as well as his or her efforts in managing the firm. We assume $K^{\prime}(I)>0$, and $K^{\prime \prime}(I)<0$; so returns to investment has diminishing returns. The output in period 1 is $e_{1} \theta_{1}+K(I)$. 
The government announces its plans to reward the enterprise with the static optimal compensation scheme: $R_{t}=a+b y_{1}$. This is justified by a well-known result in regulation theory that in a stable dynamic setup with asymmetric information, it is optimal to repeat the optimal static incentive scheme in each period. ${ }^{6}$ The government, however, deviates from the optimal in that it has a commitment problem: based on past observations, the manager expects the government to renege on its performance contract with probability $\tau(m)$. In other words,

with probability the government will compensate the manager regardless of $\tau(m): \quad$ outcomes, $R_{t}=\bar{R}_{t}$, a constant exogenously set.

with probability the government will abide by the performance contract so that $1-\tau(m): \quad R_{t}=a+b y_{1}$.

A larger $m$ implies a stronger commitment to performance contract, $\frac{d \tau(m)}{d m}<0$. The manager decides to work at the intensity $e_{t}$ at the beginning of period $t$, and decides to invest $I$ at the beginning of period 0 ; the government rewards the firm at the end of each period.

Assume the intertemporal discount rate is $\beta$, then the utility function is

$$
\begin{aligned}
W^{F}= & (1-\tau(m))\left(a+b e_{0} \theta_{0}\right)+\tau(m) \overline{R_{0}}-\psi\left(e_{0}\right)-I \\
& +\beta\left\{\left(1-\tau_{m}\right)\left[a+b\left(e_{1} \theta_{1}+K(I)\right)\right]+\tau(m) \overline{R_{1}}-\psi\left(e_{1}\right)\right\}
\end{aligned}
$$

The manager's optimal investment and effort are solved from the first order conditions:

$$
\begin{aligned}
& 1=[1-\tau(m)] \beta b k^{\prime}(I) \\
& \psi^{\prime}\left(e_{0}\right)=[1-\tau(m)] b \theta_{0} \\
& \psi^{\prime}\left(e_{1}\right)=[1-\tau(m)] b \theta_{1}
\end{aligned}
$$

The comparative-static analysis yields that 


$$
\frac{\partial X^{*}}{\partial m}>0, \text { and } \frac{X^{*}}{\partial b}>0, \text { where } X=I, e_{0}, e_{1}
$$

It then follows that $\frac{\partial y_{t}}{\partial m}>0, t=0,1$. So a stronger commitment of the government will improve the performance of enterprises by encouraging investment and inducing larger effort per period. ${ }^{7}$

\section{The Manipulative Firm}

In this subsection we consider an example in which the manager can use his or her bargaining power to ex post reduce the threshold for punishment in his or her own favor. We might not observe the manager reducing the punishment threshold in firms with substantial bargaining power because they can manipulate the performance criteria ex ante (though this manipulation does not fall under the category of commitment). In the extreme, a manipulative firm can set itself the targets within easy reach. In general, the more bargaining power a firm has (in part due to its information advantage), the easier the targets the firm can obtain; as a result, the lower the effort and learning the manager and the employees will yield, thus the worse the performance.

In firms without such strong ex ante bargaining power, or firms with such powers yet can still bargain down performance criteria ex post, we will see managerial noncommitment when the manager expects to be able to bargain down the performance criterion ex post. The government hopes to use the following performance contract, which punishes the manager with no rewards when $R_{f}<\bar{R}$, a constant:

\section{Event: $\quad$ Reward to the manager $R_{1}$ :}

Period 0: $\quad a+b e_{0} \theta<\bar{R}$ 0 


$$
\begin{array}{lll} 
& a+b e_{0} \theta \geq \bar{R} & a+b e_{0} \theta \\
\text { Period 1 } & a+b\left(e_{1}+k(I)\right) \theta<\bar{R} & 0 \\
& a+b\left(e_{1}+k(I)\right) \theta>\bar{R} & a+b\left(e_{1}+k(I)\right) \theta
\end{array}
$$

The manager ex ante agrees to the terms, knowing that in the second period he or she can bargain for a lower performance criterion $\underline{R}<\bar{R}$, and thus avoid punishment as long as $R_{1}>\underline{R}$. Then, the manager is motivated by the expectation of the ex post rewards and punishment, summarized as follows:

\section{Event: $\quad$ Reward to the manager $R_{t}$ :}

$$
\begin{array}{lll}
\text { Period 0: } & a+b e_{0} \theta<\bar{R} & 0 \\
& a+b e_{0} \theta \geq \bar{R} & a+b e_{0} \theta \\
\text { Period 1 } & a+b\left(e_{1}+k(I)\right) \theta<\underline{R} & 0 \\
& a+b\left(e_{1}+k(I)\right) \theta>\underline{R} & a+b\left(e_{1}+k(I)\right) \theta
\end{array}
$$

A crucial but plausible assumption for the following proof is that $\theta \varphi(\theta)$ is monotonously increasing over the relevant range when $\theta$ belongs to the range defined by $\underline{R}<R_{t}<\bar{R} .{ }^{8}$ In our context, since the government is likely to set $\bar{R}$ well below the mean or the median of $\theta$, and $\underline{R}$ is even lower, $\theta \varphi(\theta)$ is most likely increasing over the range bounded by the two thresholds.

Now compare the objective functions with and without managerial commitment. The manager is committed when he or she exerts effort to exceed the punishment threshold $\bar{R}$ in both periods, and is not committed when he or she expects to bargain down the punishment threshold to $\underline{R}(\underline{R}<\bar{R})$ in the second period. The managerial objective functions with and without commitment differ only when $\underline{R}<R_{1}<\bar{R}$. Therefore, 
(14) $U_{N C}-U_{C}=\beta \int_{\frac{\underline{R}-a}{b\left(e_{1}+K(I)\right)}}^{\frac{\bar{R}-a}{b\left(e_{1}+\bar{K}(I)\right)}}\left(a+b \theta\left(e_{1}+K(I)\right) \varphi(\theta) d \theta\right.$

Obviously, optimal $e_{0}$ is the same with or without managerial commitment. Yet, optimal $e_{1}$ and $I$ will decrease, as the following can be proved: ${ }^{9}$

$$
\begin{gathered}
{ }^{M R}{ }_{N C}^{e_{1}}-M R_{C}^{e}{ }^{e}<0 \\
M R_{N C}^{I}-M R_{C}^{I}<0
\end{gathered}
$$

Thus in this example, relative to managerial commitment, managerial noncommitment leads to declining efforts of managers over time, and a suboptimal investment. Empirically, managerial non-commitment to contract should be shown in decling stringency of targets over time.

\section{Empirical Application}

Our model suggests that information asymmetries lead governments to provide low powered incentives that don't induce managers to exert as much effort as under perfect information. It further predicts that lack of commitment will also lead to lower performance. To test these hypotheses we first examined how performance contracts addressed problems of information, incentives and commitment in a sample of twelve companies in six countries, as shown in table 2. (For ease of reading we have used simplified enterprise names; see table 2.) We then measured performance trends after the year of the contract and compared them with pre-contract trends. 
Our analysis is based on the contract documents and reports from the monitoring agency, a questionnaire administered to each sample company and government monitoring agency, World Bank file data, interviews in the field and with knowledgeable World Bank staff, and the enterprises' own audited accounts and reports. ${ }^{10}$ The sample is small and not random, so care must be used in generalizing from the results. ${ }^{11}$ Also there are weaknesses in the data: accounting is weak in Ghana and Senegal, and in some cases our precontract period is short and the length of the postcontract period varies, which makes it hard to measure trends. ${ }^{12}$ Even so, the sample does include countries at very different levels of income that employed varying approaches to performance contracting. An improvement in postcontract performance across such differing country and contract experiences would suggest that the contracts can reduce the three contracting problems (unless other exogenous factors were at work, something we also investigated). ${ }^{13}$

\section{A. Information Asymmetries and Incentives}

Our first hypothesis is that in the presence of information asymmetries governments are likely to use lower powered incentives. Competition between firms for the market or bidding between potential managers for the privilege of operating the firm increases government's information by allowing comparisons between the firms' performance or the managers' bids. However, all of the sample enterprises were monopolies and none of the contracts were competitively bid, so this form of information revelation was not employed.

The information disadvantage of governments was also manifested by that all of the government agencies responsible for negotiating, monitoring and evaluating (henceforth 
supervisors) used SOEs' annual, audited accounts for the information, but the quality of these data varied, and in five of the cases (three in Ghana and two in Senegal) were very poor. For example, in 1991, twelve of the seventeen SOEs supervised by the State Enterprise Commission of Ghana (or SEC) were seven weeks late in delivering their 1990 fourth quarter results. Only five of the firms had current audited accounts; the most recent audited accounts for the others ranged from one to three years old (State Enterprise Commission 1991). Similar problems were cited in interviews in Senegal, where enterprises were also reported to evaluate themselves. ${ }^{14}$ Moreover, as we show below, the enterprise managers had considerable bargaining power in all the cases except the two SOEs in Korea, which made it difficult for the government supervisors to demand better information. The low status and pay of the government bureaucrats responsible for supervising the contracts meant that the skills available to assess and process the information were also low. Korea, and to a lesser extent, India, used outside experts to supplement the skills of the bureaucrats which helped reduce its information problems (see section III.C).

As expected, the information problems led to low powered incentives. ${ }^{15}$ Managers and staff could receive a pecuniary bonus for good achievement of their targets in only two of the 12 sample contracts (Korea Electricity and Korea Telecoms). In the two Korean cases, the staff of the company could get a bonus of up to three months salary for "A" graded performance. Bonuses are also part of the contracts in the three sample contracts in Ghana, but according to survey responses promised bonuses have not been paid. In two other contracts (India Electricity and Oil) managers could receive an award 
for good performance in a public ceremony, but interviews suggest that this was not viewed as a very strong motivation.

Thus, with the exception of Korea, governments opted for low powered incentives. The bonuses in Korea were high powered incentives in part because they were paid to all staff; managers reported feeling pressured to improve performance so as not to disappoint their employees (Shirley 1990). Moreover, bonus ratings were reported in the media, which managers stated was a strong motivating force (Ibid.). Since Korea had less information problems than the other countries, its experience lends support to our conjecture that information asymmetry leads to lower power incentives.

\section{B. Lack of Government Commitment}

Our model next suggests that the expectation that government will renege will lead managers to underinvest in improving the performance of their firms. While the model suggests one way governments might renege is by not paying the promised bonus, the government could also renege by not taking the actions necessary for management to achieve the targets. Governments made explicit promises in all but four of the contracts (the exceptions are the two Korean and two Philippines contracts) to take actions that were crucial to the successful achievement of the targets. Although the contracts in the Philippines did not include such obligations, many of the targets (such as financial and profitability measures in current prices or labor productivity) partly depended on government actions (such as allowing tariff adjustments or lay offs) to be achieved, which could be taken as an implicit promise. Only in the cases of Korea Telecoms and Electricity were the targets - for example, transmission losses, thermal efficiency, 
minutes of outages per household, and profitability in constant prices-not directly dependent on government decisions. The governments in our sample not only controlled prices of factors and products, decisions about wages and layoffs, procurement above minimal levels, and all senior appointments, they also strongly influenced whether the SOE was paid by its customers (and had to pay its suppliers or creditors). Eighty eight percent of respondents to our questionnaire cited one of the factors under government control (hiring, firing, payment of government's and other SOEs' receivables to the firm, pricing policy, etc.) as the number one obstacle interfering with the achievement of the objectives of the contracts. ${ }^{16}$

To assess whether government was credible in its commitment to provide the promised incentives and to honor its promises under the contract, we looked for the presence of enforcement mechanisms. We also checked whether governments took costly actions to signal commitment to managers (see Spence 1973; Lupia and McCubbins 1996) for discussions of costly action to signal credibility). Since the sample contracts were all repeated games (most were annual, see table 2), we also looked at government's compliance in the early contracts as a signal of its credibility in later contracts.

Enforcement. None of the contracts specify an enforcement mechanism in the sense of a neutral third party, insulated from politics, with the power and information to compel both parties to comply. In several cases, however, government obligations were potentially enforceable by an outside party. The World Bank included government contractual obligations as covenants in its loans for SOEs in Ghana, Mexico and Senegal. 
(Although these covenants were drawn up on the basis of project or sector needs rather than because they were part of the contracts, governments' agreement to the World Bank loan could be interpreted as a signal of commitment to the contract as well). Interviews suggested that the influence of this outside involvement was mixed. It may have helped the contracts' credibility in Ghana and Mexico, but it appears to have reduced the contracts' credibility in Senegal. Survey respondents and other observers agreed that the contracts in Senegal were viewed by the signatories as donor driven and not as credible obligations. The suspension of disbursement of a World Bank loan to Senegal Electricity after government reneged on its contract obligations to settle arrears to the company did not change government behavior and penalized the company as much as, if not more than, the government. The contract expired in 1989; by mid-1995 the government and Senegal Electricity management had yet to agree on a new contract. The role of outside pressure from agencies such as the World Bank is necessarily a limited one, since such agencies are not party to the contract and have, at best, only an indirect stake in the outcome.

The participation of private individuals (non-government accountants, lawyers, and academics) and a prestigious government think tank, the autonomous Korea Development Institute, may have increased the credibility of government's commitment to the contracts with Korea Electricity and Telecoms. Knowledgeable outsiders may have informally monitored the government supervisors and acted as a check on government actions that would have violated the contract. Moreover, they had a more direct stake in the outcome, than, for example, the World Bank; such outsiders stated in interviews that they felt their 
reputation was on the line in the highly publicized evaluation process in Korea (Shirley 1991). India also used outside evaluators, although their role was more limited then in Korea where the outside team had primary responsibility for evaluation.

Costly Action. Many of the government actions promised in the contracts were politically costly. For example, since SOE jobs are used to reward political supporters in many countries (Shleifer and Vishny 1994), allowing managers to lay off redundant workers would be a strong signal of commitment to the contract. It would also be politically costly to divert revenues from other uses to pay government bills to the firm and to fund government mandated investments, allow the firm to pursue its creditors and apply legal penalties if they did not pay, and regulate monopoly prices according to clear and reasonable rules that would allow the firm enough revenue to service its debt, maintain and improve service, upgrade technology, and expand to meet demand (which would mean price increases for powerful consumers). Costly signals were sent only in the contracts with the two SOEs in Korea. When performance contracts were introduced in Korea in 1983-84, managerial autonomy of the two SOEs in our sample (and of all other so-called Government Invested Enterprises) was increased. ${ }^{17}$ This seems to have boosted the contracts' credibility with managers and employees. ${ }^{18}$ However, some of those interviewed cited waning government commitment to performance contracting in Korea in recent years, raising doubts about whether this credibility had been sustained. ${ }^{19}$

Reneging. The model suggests that if governments renege by failing to pay the promised incentives to managers who achieve their performance targets, the SOEs will yield sub-optimal performance. In three of the five contracts where bonuses were part of 
the agreement (the contracts with the three SOEs in Ghana) government reneged on its promised incentive payments. Governments also reneged on the promises they made from the beginning of the contract process in Ghana, India and Senegal (table 3). This early reneging hurt the credibility of government commitment to the subsequent contracts. For example, every year the contract for India Electricity promised government help in enforcing prompt payment from its customers, the State Electricity Boards, yet accounts receivable went from 149 days in 1986, the year before the contract was introduced, to 207 in 1990; in 1991 they fell to 150 days when a power plant was turned over to the SOE in partial payment of arrears. Similar reneging occurred in the first contracts in Senegal. We already described Senegal Electricity's refusal to sign a second contract. The government's failure to honor its obligations to Senegal Telecom evoked this comment in a 1989 company report: "It must be remembered that the contract plan was never considered a binding contract by the public powers."

Government credibility may have been greater in the contracts in Ghana, since the government met some of its early promises. For example, even though the government of Ghana did not always approve Ghana Water's tariff increases promptly and required the company to serve some nonpaying customers, it did increase tariffs in real terms and support management in reducing the work force. Furthermore, all three contracts in Ghana provided for recalculation of targets if government reneged on its contractual obligations. Although this betrays a disconcerting expectation that government will renege, it also means that SOEs were not penalized for government misbehavior. As we mentioned, the Mexican government met its obligations in the contract with the 
Electricity Company, albeit with some delay. ${ }^{20}$ Finally, the Government of the Philippines reneged on its implicit promises by, for example, not requiring the public sector to promptly pay its bills to the SOEs.

In sum, due to weak enforcement, lack of costly signals and/or early reneging, government commitment to the performance contracts in Ghana, India, the Philippines and Senegal was not credible, while the Mexican contract may have been marginally credible. Only Korea managed to formulate targets that were not directly dependent on government action, institute an enforcement mechanism that used outside evaluators to enhance credibility, and take costly action to signal commitment.

\section{Lack of Management Commitment}

The model suggests that if managers lack commitment and have bargaining power they will try to avoid punishment when their performance falls below target. We looked for evidence of managerial bargaining power by comparing the status of the SOE negotiators with the status of the government supervisors responsible for negotiating, monitoring and evaluating the contracts. We also analyzed the targets for evidence that managers were manipulating the performance criteria.

Managerial Bargaining Power. In all but Korea and India (where outsiders played a role, described above) contracts were negotiated, monitored and evaluated by middle- or low-level civil servants, while the SOE's representatives were better paid and had much higher status. For example, in Ghana the SOEs were often represented at the bargaining table by a managing director with status equivalent to a cabinet minister (and better pay), while the government supervisory agency was usually represented by a low-level 
functionary. ${ }^{21}$ In contrast, Korea's contracts are evaluated by an ad hoc task force composed of private individuals (nongovernment accountants, lawyers, academics, etc.) and a prestigious government think tank, the autonomous Korean Development Institute. However, the negotiations in both Korea and India were done by the government bureaucrats. The lower status of the government supervisors made it hard for them to negotiate tough targets and demand the information necessary for evaluating performance or to give the SOEs an unsatisfactory score. Outsiders were more likely to rival the status of the SOE representatives and be able to overcome some of the managers' bargaining power. However, since the outsiders in both Korea and India were brought into the process on an ad hoc basis their lack of continuity may have reduced their opportunity to learn about the company's performance over time.

Asymmetry in the status of the government supervisory agencies vis-à-vis the managers was aggravated in some of our sample contracts because supervisors were weakened by frequent changes in responsibilities and authority. Specifically, the supervisory agency in Senegal was moved twice after contracting began (from the Presidency to the Prime Minister's office to the Ministry of Finance). According to interviews, these moves diluted its authority vis-à-vis the enterprises. Similar changes undermined the authority of the responsible agencies in the Philippines (where the supervisory agency also has a high rate of staff turnover) and Ghana. ${ }^{22}$ In contrast, the contracts in India, Mexico and Korea were negotiated, monitored and evaluated by more stable agencies. 
We expected that if managers are not committed they would manipulate the targets to avoid punishment. Punishment was avoided by most of our sample SOEs. Only in the case of the two Korean contracts was there any evidence that management achievements had some effect on managerial careers (Shirley 1991); interviews in the other countries revealed that managers' job assignments were largely politically determined and not driven by performance. ${ }^{23}$ None of the sample received a less than satisfactory grade against the contract criteria, so there was no basis for government to discipline the managers or not pay the promised incentives. This suggests that an important manifestation of low managerial commitment was bargaining for targets that could be attained without increased investment or effort.

Targets. There is anecdotal evidence that some targets are easily attained:

- Senegal Telecom's target for call completion rates was lower in the 1986 performance contract than in the company's business plan of ten years before. In 1992 the call completion rate was a mere 55 percent in Dakar and less than 40 percent for interurban calls, about half the international industry standard.

- In India, negotiations on targets sometimes dragged on so long that the targets were set to be the same as actual performance. ${ }^{24}$

- In Ghana contract targets were set by the companies themselves; the supervisory agency considered many targets too low and established a penalty for under-targeting (State Enterprise Commission 1991).

- In the Philippines, one of Philippines Electricity's most important and difficult challenges was to improve its reliability, but its reliability indicator (the percentage of 
electricity which its customers have contracted for but the company never supplied) became less important in its performance score, falling from 30 percent of total targets in 1990 to 10 percent in 1991 and 15 percent in 1992 . This is not because the firm became more reliable; on the contrary, by 1992-93 outages of seven hours per day were common in many parts of the country. ${ }^{25}$

- Korea used a comprehensive target for assessing performance of the sample enterprises, public profitability in constant prices. (This indicator follows a trend very close to total factor productivity and can be calculated using shadow prices to account for price distortions; as a target it would be had to manipulate.) ${ }^{26}$ The share of public profitability in the contracts for Korea Telecoms and Electricity fell from 20 percent to 12 percent from 1985 to 1992 . Field interviews suggest that this occurred because SOE managers successfully negotiated the addition of other targets at the expense of public profitability.

Besides this anecdotal evidence there is comprehensive evidence that all of the sample contracts had targets which put the government supervisors at a serious disadvantage vis-à-vis the enterprise representatives. All but two of the sample contracts had either many targets (seven had more than 20 targets on average) or targets which changed frequently (four changed more than 20 percent of their targets a year on average), or both (figure 1). For example, Korea Telecoms' contracts had about 40 targets, most with weights of 1 percent or less. On average, over one third of the targets in the contracts with the three SOEs in Ghana changed every year. Each time a new criterion is added, evaluators had to decide on the criterion value-what constitutes good, 
fair, or poor performance. Recall that the targets in performance contracts for SOEs were based on improvements over past performance, rather than some objective standard, which required the government supervisors to learn about what constituted good performance for each individual firm. Learning which values are hard and which soft is more difficult when criteria are numerous or constantly changing. ${ }^{27}$

One way to make it easier to judge performance is to assign a weight to each target so they add up to 100 percent and the supervisor can calculate an aggregate score. While most of our sample used weighted targets (the exceptions are in Senegal and Mexico), fluctuations in the weights frequently offset this advantage, adding another layer of complexity and uncertainty. For example, the weight assigned to India Oil's financial targets went from 20 percent in 1989 to 12 percent in 1990 , then climbed to 40 percent by $1992 .^{28}$

Such numerous, unstable, and increasingly less stringent targets indicate that uncommitted managers were exploiting their bargaining power to negotiate targets that maximized their information advantage. And indeed, field interviews suggested that managers often negotiated for changes or additions to targets. However, another factor may also be partly responsible. As mentioned, SOEs faced numerous objectives from multiple principals; the government supervisors may have had trouble mediating among the different vies and opted for numerous, relatively evenly weighted targets. Since the political strength of the principals changed from time to time, this could account for some of the fluctuations in the targets. ${ }^{29}$ 
In sum, the managers in our sample had bargaining power and used it to manipulate the performance criteria to avoid penalty or to assure reward, as the model suggested.

\section{Contracting Problems: Summary}

Our model suggests three ways in which performance contracts might fail; as figure 1 shows, all but the two contracts with the SOEs in Korea evidence all three kinds of failure: low power incentives stemming from information asymmetries; lack of government commitment; and lack of managerial commitment. Korea does better than the rest of the sample on the first two, but fails on managerial commitment. The next sections examines how the contracts did in improving SOE performance.

\section{The Impact of the Contracts on Performance}

Our next task was to determine whether enterprise performance changed in ways that could be attributed to the contract (or, more weakly, in ways that the contracts could not be ruled out as explanatory factors). To assess the companies' economic performance we compared trends in profitability (return on assets, or ROA), labor productivity (LP) and total factor productivity (TFP) before and after the introduction of the contract. ${ }^{30}$ ROA was calculated as sales minus cost of goods sold and depreciation over revalued fixed assets. ${ }^{31}$ TFP was calculated as the constant value of production over the constant costs of all production factors (labor, intermediate inputs and capital), using company volume data to construct company-specific price indices for each factor and output where available; otherwise we used the relevant country-specific price indices. LP was calculated as the real value of production divided by the number of workers. 
Our counterfactual was based on the trend in the three measures before the contract was introduced. We assumed that if the contracts made a difference we would see a noticeable kink in trend in the period after the year in which the contract was introduced. A noticeable kink was defined as a move from a negative trend to a positive trend (or vice versa), or a more than doubling of the rate of change. We had to use relatively stringent criteria because of the small sample size and the lack of a control (such as an SOE without a contract).

A frequent question is why did we not assess how well the firms did on their noneconomic objectives, especially since some observers consider these more important for a state enterprise than its economic objectives, and success in these goals may be responsible for (and outweigh) failures in economic performance measures? Since 75 percent of the respondents to our questionnaire saw improving profitability or efficiency as the number one objective of the contracts and 88 percent, as objective number one or two, and since two thirds of the score of the enterprises were based on economic achievements, we deemed improvement on ROA, LP and TFP as better measures of the success of the contracts than non-economic achievements. ${ }^{32}$ Moreover, as we noted in the introduction, an important rationale for performance contracts is to maximize economic performance within the constraints of non-economic goals. ${ }^{33}$

Profitability. None of the twelve sample companies improved their trend in ROA after the contract. Nine continued to improve or deteriorate without a noticeable change in their trends, while three showed worse ROA trends after contracts than before (Philippines Electricity, Senegal Electricity, and Senegal Telecoms; see figure 2). ROA 
trends in state-owned enterprises may reflect government behavior more than managerial behavior, since the sample's product prices were controlled by the government. (Some important factor prices were also controlled; for example, government set prices for Senegal Electricity's petroleum inputs at about twice world market prices in the 1980s without always allowing it to raise its price to the consumer. $)^{34}$ The profitability trends in the sample suggest that the contracts had little impact on government's pricing behavior. Only one company did better because of government mandated price increases (Philippine Water), and these gains were not enough to change its almost flat trend in ROA. As for the deteriorating firms, one (Senegal Telecom) shows worse ROA because of government pricing decisions, mainly because the government reduced its very high base tariffs.

Labor Productivity. Labor productivity growth was positive in all twelve cases, but the data suggest that the contracts had little impact on this trend. Only two companies show a kink in their labor productivity trends (declining labor productivity began to increase in Senegal Telecoms, and the rate of increase in labor productivity more than quadrupled after the contract in Ghana Water; see figure 3.); in the rest, labor productivity continued its precontract trend upward. In only four of the twelve cases was labor productivity growth primarily due to the shedding of excess workers (plus the removal from the rolls of "ghost workers"). Consistent with this finding, 53 percent of respondents to the questionnaire $(\mathrm{N}=17)$ ranked inability to dismiss unnecessary workers as the number one obstacle to achieving the contract's goals. In the other eight, production gains outstripped employment increases. Since labor productivity could be 
raised by increasing the use of other factors, rather than by improving overall efficiency, we considered TFP a more reliable indicator of efficiency improvement.

Total Factor Productivity. Performance on TFP is mixed. In three of the twelve companies (Ghana Water, Mexico Electricity, and Senegal Telecoms) declining TFP began to increase after the contracts were introduced, while three others (India Electricity, Philippines Water and Senegal Electricity; see figure 4) suffered a downturn in what had been an improving TFP trend. The six remaining firms continued their precontract trends upward. This ambiguous finding shows no strong relation between the contracts and TFP.

Exogenous Factors. Our performance measures suggest that the contracts had little positive impact, as figure 5 shows. To assess whether this could be attributed to other factors which might have blunted or negated the influence of the contracts, we first checked for the presence of any exogenous factors that could have affected the performance trends. Specifically we looked for important changes in input or output markets or prices, natural or man-made disasters, major work stoppages or any other major events reported in the companies' annual reports or cited by country and company experts. We also compared the companies' trends with trends in other variables (notably with GDP growth) to see if an acceleration or deceleration in growth might have affected performance. $^{35}$

In two cases we found exogenous factors which might have influenced trends -Philippines Electricity and Senegal Telecoms. The postcontract return on assets of Philippines Electricity was adversely affected by increases in the cost of imported oil, but this cannot explain its poor performance in constant priced TFP. TFP might have been 
adversely affected by disruptions caused by the Luzon earthquake, plus devastating typhoons in 1989 and 1990; however, observers knowledgeable about the company regard its performance as consistently weak. Moreover, other disasters (the Mt. Pinatubo eruption and Ormoc flood in 1991) had not prevented the firm from recovering its productivity levels.

Senegal Telecom may have benefitted from the fact that it was split off from the postal service in 1986, the first year of the contract. Although we have tried to isolate the telecommunications side prior to this split, that may not always have been possible, and could cause the period before the contract to look worse than it otherwise would. (The split itself is not strictly exogenous; even though it was not explicitly part of the contract, it was part of the agreement with the World Bank to implement the two together and a case could be made that they were interdependent.) In any event, if the Senegal Telecom improvement is indeed overstated, it would strengthen our finding that the contracts had no discernable positive impact on performance.

\section{Conclusions}

Only three of the twelve case study companies showed a turnaround in TFP after contracts were introduced, six continued their past trends, and three performed substantially worse under contracts than before. Labor productivity improved at a faster pace in four cases, and deteriorated in none, but for most SOEs the improvement long predates the contracts. ROA deteriorated in three firms; the rest showed little change. 
Thus, the evidence from this sample gives little support to the premise that explicit contracts helped improve SOE performance.

If we compare the contracting problems in figure 1 with contract performance we also see no clear patterns. The contracts with the least problems (Korea Electricity and Telecom) were with companies which showed no change in performance; the two SOEs continued their pre contract (improving) trends. Since these contracts had problems of managerial commitment, this may be a necessary condition for performance contracts to have a positive impact on performance.

As we mentioned, performance contracting assumes that government's objectives can be maximized, and performance improved, by setting targets which take into account the constraints placed on managers. For this to occur, the principals will need to be willing explicitly to state their objectives, assign priorities to multiple objectives (by assigning weights), translate these objectives into targets aimed at performance improvement, provide incentives to meet these targets (or monitor the agents without incurring substantial costs), and credibly signal their commitment to the contract.

All these assumptions failed to materialize in our sample, First, with the exception of Korea, the governments negotiating our sample contracts chose to hide their true objective functions and pledge actions that they were not motivated to implement. Second, with the exception of India, Korea and Mexico, the supervisory agencies were given neither the capacity nor the incentives to negotiate, monitor and evaluate well. Their information disadvantage was reinforced by other government actions, such as giving them low pay and status, frequently moving them within the government and 
failing to force the SOEs to comply with their information requirements. Most of the contracts fell victim to information asymmetries which led governments to set incentive mechanisms too low to persuade managers to comply.

Why would governments introduce the contract process and then not try to make it work? Some governments may have been motivated to make promises that were politically unrealistic because the contracts allowed them to earn foreign assistance. Such assistance might not have been forthcoming if they could only promise the marginal improvements possible without changes in government behavior. This may have been the case in the contracts in Senegal and Ghana where the negotiating agents pledged actions (regular increases in tariffs, end to arrears) that were not politically possible, and in the Philippines, where target achievement depended on government actions that were politically unlikely. That they did this knowingly is suggested by the fact that the problems they pledged to correct were long standing and had proved immutable.

Less hard to interpret is the lack of commitment of the managers. In contrast to a private firm, the SOE managers in our sample had little choice but to sign the contract (the case of Senegal Electricity notwithstanding). Not surprisingly, managers with information advantages and bargaining power, and without high powered incentives or credible commitment from government, chose to use their advantages to manipulate the targets so as to assure that their performance would be judged as satisfactory. In essence, the sample performance contracts failed to reduce the problems caused by the absence of a clear residual claimant with a direct financial stake in the SOE's surplus. 
This analysis has policy implications for developing country governments considering performance contracts. Such contracts will only succeed if the contracting problems described here can be overcome. This suggests that contracting governments will need to:

- Reduce information asymmetries by improving accounting practices and the skills of negotiators and evaluators. Where market failures don't rule out competition, information could be improved by breaking up monopolies; where products are homogeneous or easily compared, and technology is relatively simple and stable, information could be enhanced by allowing managers to bid for the contract. ${ }^{36}$

- Give the bureaucrats and other actors involved the contract discussions independence, adequate pay, stability and the power to punish intentional misinformation or withholding of information.

- Clearly specify and enforce high powered rewards and penalties when the government has adequate information.

- Take politically costly actions at the outset and throughout the process to signal to managers that they will have enough freedom to achieve their targets, such as allowing layoffs of redundant workers or by regulating prices to permit an efficient firm to earn a reasonable return.

- Set up and abide by a neutral, third party enforcement arrangement (such as an arbitration board).

- Design a contract with few (two or three) comprehensive, weighted targets, which are stable over a period of time. 
- Design self-enforcing contracts, by, for example, making managers post a bond that they will forfeit if they fail to meet the agreed targets (as was done in China, for example).

Whether a performance contract will succeed if all of these measures are implemented is an open question. Our sample is small, and it is not representative of the contracts used in transitional economies for competitive SOEs; we lacked controls (SOEs without contracts), and we used relatively stringent criteria for assessing performance change. ${ }^{37}$

Since all the contracts failed to improve performance, we cannot say with certainty whether or not a well designed contract would have done better. Also unknown is whether alternatives which create a residual claimant, such as contracts with private managers or sale of the enterprise to a private owners, might produce better results (although findings in World Bank 1995 are very suggestive). What is clear is that, if the contracts in our sample are representative of the performance contracts in use with natural monopolies worldwide, then considerable time and effort is being expended on an exercise with neither theoretical nor empirical justification. 


\section{Appendix A: The Derivation of Equation 11}

$$
\begin{aligned}
\frac{\partial W}{\partial b} & =v\left\{p \underline{\theta} \underline{e^{\prime}}-(1+\lambda) b \underline{\theta} \underline{e}^{\prime}\right\}+(1-v)\left\{p \bar{\theta} \overline{e^{\prime}}-b \bar{\theta} \overline{e^{\prime}}-\lambda b \underline{\theta} \underline{e}^{\prime}-\lambda(\bar{\theta} \bar{e}-\underline{\theta} \underline{e})-\lambda b\left(\bar{\theta} \overline{e^{\prime}}-\underline{\theta} \underline{e^{\prime}}\right)\right. \\
& =v(1+\lambda)(s-b) \underline{\theta} \underline{e}^{\prime}+(1-v)\left\{p \bar{\theta} \overline{e^{\prime}}-(1+\lambda) b \bar{\theta} \overline{e^{\prime}}+\lambda b \bar{\theta} \overline{e^{\prime}}-\lambda b \underline{\theta} \underline{e}^{\prime}-\lambda b\left(\bar{\theta} \overline{e^{\prime}}-\underline{\theta} \underline{e} \underline{e}^{\prime}\right)-\lambda(\bar{\theta} \bar{e}-\underline{\theta} \underline{e})\right\} \\
& =v(1+\lambda) \underline{\theta} \underline{e}+(1-v)(1+\lambda)\left\{(s-b) \bar{\theta} \overline{e^{\prime}}-\lambda(1-v)(\bar{\theta} \bar{e}-\underline{\theta} \underline{e})\right\} \\
& =(1+\lambda)\left\{(s-b)\left[v \underline{\theta} \underline{e}+(1-v) \bar{\theta} \overline{e^{\prime}}\right]-\frac{\lambda}{1+\lambda}(1-v)(\bar{\theta} \bar{e}-\underline{\theta} \underline{e})\right\}
\end{aligned}
$$

Setting this to zero yields equation (11). Q.E.D.

\section{Appendix B: The Proof of the Two Inequalities}

The Proofs for the two inequalities are mirror images, so we shall only prove the last one.

Denote $\underline{\theta}=\frac{\underline{R}-a}{b\left(e_{1}+K(I)\right)}, \bar{\theta}=\frac{\bar{R}-a}{b\left(e_{1}+K(I)\right)}$; note that $\bar{\theta}>\underline{\theta}$. Then take derivative with respect to $I$ (for equation (24)), and we get

$$
\begin{aligned}
& \frac{M R_{N C}^{I}-M R_{C}^{I}}{\beta}=\int_{\underline{\theta}}^{\bar{\theta}} b \theta K^{\prime}(I) \varphi(\theta) d \theta+\bar{R} \varphi(\bar{\theta}) \frac{\bar{R}-a}{b} \frac{-K^{\prime}(I)}{\left(e_{1}+K(I)\right)^{2}}-\underline{R} \varphi(\underline{\theta}) \frac{\underline{R}-a}{b} \frac{-K^{\prime}(I)}{\left(e_{1}+K(I)\right)^{2}} \\
& =\int_{0}^{\bar{\theta}} b \theta K^{\prime}(I) \varphi(\theta) d \theta-\int_{0}^{\theta} b \theta K^{\prime}(I) \varphi(\theta) d \theta-\bar{R} \varphi(\bar{\theta}) \bar{\theta} \frac{K^{\prime}(I)}{e_{1}+K(I)}+\underline{R} \varphi(\underline{\theta}) \underline{\theta} \frac{K^{\prime}(I)}{e_{1}+K(I)} \\
& =b K^{\prime}(I)\left\{\left[\int_{0}^{\theta} \theta \varphi(\theta) d \theta-\bar{\theta}^{2} \varphi(\bar{\theta})\right]-\left[\int_{0}^{\theta} \theta \varphi(\theta) d \theta-\underline{\theta}^{2} \varphi(\underline{\theta})\right]\right\}+\frac{a b K^{\prime}(I)}{b\left(e_{1}+K(I)\right)}\{\underline{\theta} \varphi(\underline{\theta})-\bar{\theta} \varphi(\bar{\theta})\}
\end{aligned}
$$

We now show that the terms in both $\{$.$\} are negative, thus the above equation is negative. The$ term in the first $\{$.$\} is negative because \int_{0}^{x} \theta \varphi(\theta) d \theta-x^{2} \varphi(x)$ is monotonically decreasing in $x$ :

$$
\frac{\partial}{\partial x}\left[\int_{0}^{x} \theta \varphi(\theta) d \theta-x^{2} \varphi(x)\right]=-x\left(\varphi(x)+x \varphi^{\prime}(x)\right)<0
$$

the right hand side is non - positive because by assumption, $x>0$, and $\theta \varphi(\theta)$ increases in $\theta$, thus, $\varphi(\theta)+\theta \varphi^{\prime}(\theta)>0$.

The second $\{$.$\} term is negative because of the same assumption: \theta \varphi(\theta)$ increases in $\theta$, and $\bar{\theta}>\underline{\theta}$. Q.E.D. 


\section{References}

Barron, David. 1988. "Design of Regulatory Mechanisms and Institutions," in R. Schmalensee and R. Willing (eds). Handbook of Industrial Organization. Amsterdam: North-Holland.

Besanko, David and David Sappington. 1987. Designing Regulatory Policy with Limited Information. London: Harwood Academic Publishers.

Dyer Cissé, Nichola. 1994. “The Impact of Performance Contracts on Public Enterprise Performance." Background paper. Policy Research Department, World Bank, Washington, D.C.

Freixas, Xavier, Roger Guesnerie, and Jean Tirole. 1985. "Planning under Incomplete Information and the Ratchet Effect." Review of Economic Studies. LII: 173-191.

Jones, Leroy. 1975. Public Enterprise and Economic Development: The Korean Case. Seoul: Korea Development Institute.

. 1981. "Towards a Performance Evaluation Methodology for Public Enterprises: With Special Reference to Pakistan." Paper presented at the international symposium on Economic Performance of Public Enterprises, Islamabad.

. 1985. "Public Enterprise for Whom? Perverse Distributional Consequences of Public Operational Decisions." Economic Development and Cultural Changes 33 (2): 333-47.

Laffont, Jean-Jacques, and Jean Tirole. 1986. "Using Cost Observation to Regulate Firms.” Journal of Political Economy. 94, Part 1:614-41.

1993. A Theory of Incentives in Procurement and Regulation. MIT Press: Cambridge, MA

Levy, Brian, and Pablo Spiller, eds. 1996. Regulations, Institutions, and Commitment: Comparative Studies of Telecommunications. New York: Cambridge University Press.

Lupia, Arthur and Mathew D. McCubbins. 1996. The Triumph of Reason: Knowledge and the Foundation of Democracy. New York: Cambridge University Press.

Nalebuff, Barry and Joseph Stiglitz. 1983. "Information, Competition, and Markets." American Economic Review. 73(2):278-283. 
Nellis, John 1989. "Contract Plans and Public Enterprise Performance." Policy, Planning, and Research Working Paper 118. World Bank, Washington, D.C.

North, Douglass C. 1990. Institutions, Institutional Change, and Economic Performance. New York: Cambridge University Press.

, and Barry R. Weingast. December 1989. "Constitutions and Commitment: The Evolution of Institutions Governing Public Choice in Seventeenth-Century England." The Journal of Economic History. Vol. XLIX. No. 4.

Sappington, David E. M. 1991. "Incentives in Principal-Agent Relationships.” Journal of Economic Perspectives 5 (2): 45-66. , and Joseph E. Stiglitz. 1987. "Privatization, Information, and Incentives." National Bureau of Economic Research (NBER) Working Paper 2196. Harvard University, Cambridge Mass.

Shirley, Mary. 1989. "Evaluating the Performance of Public Enterprises in Pakistan." Policy, Planning, and Research Working Paper 160. World Bank, Washington, D.C.

. 1991. "Improving Public Enterprise Performance: Lessons from South Korea." Annales de l'economie publique sociale et coopéative 62 (1). De Boech Université, Brussels.

Shleifer, Andrei and Robert W. Vishny. 1994. "Politicians and Firms." Quarterly Journal of Economics. 109:995-1024.

Spence, A. Michael. 1973. "Job Market Signalling." Quarterly Journal of Economics. 353-374.

State Enterprises Commission (SEC). 1991. SOE Performance Evaluation Report. Accra, Ghana.

1993. The SOE Reform Program 1984/1992: Review and Recommendations. Accra, Ghana.

Stiglitz, Joseph E. 1989. The Economic Role of the State. Basil Blackwell, Inc. Cambridge, MA.

Trivedi, Prajapati, ed. 1990. Labor Redundancy in the Transport Sector: The Case of Chile. Washington, D.C.: World Bank. 
Vickers, John and George Yarrow. 1988. Privatization: An Economic Analysis. Cambridge, MA.:The MIT Press.

Weitzman, Martin L. "The Ratchet Principle and Performance Incentives." The Bell Journal of Economics. 11 (1):302-08.

Williamson, Oliver. 1975. Markets and Hierarchies. New York: The Free Press. . 1976. "Franchise Bidding for Natural Monopolies - in General and with Respect to CATV." Bell Journal of Economics 7 (1): 73-104. 1985. The Economic Institutions of Capitalism: Firms, Markets, Relational Contracting. New York: Free Press.

World Bank. 1995. Bureaurcrats in Business: The Economics and Politics of Government Ownership. Washington, D.C.: Oxford University Press. 
${ }^{1}$ State owned enterprises were defined as government owned or government controlled economic entities that generate the bulk of their revenues from selling goods and services. (See Jones 1975). This definition includes all government owned enterprises where government controls the appointment of management either through its ownership stake or, in cases where government owns a minority of the shares, the distribution of the remaining shares gives government control. It excludes state owned activities such as education or health services, that are financed in other ways, such as from government's general revenues. (World Bank, 1995, Box 1.1)

${ }^{2}$ See also Milgrom and Roberts 1992.

3 . Also see Laffont and Tirole (1993)

${ }^{4}$. Since $y$ could be any other performance criterion, such as $\log ($ output) , the linear assumption is not as restrict as it looks.

5 . If interested, see appendix A for the derivation.

6. See Laffont and Tirole (1993).

7 . In another subtle way, the government can show its non-commitment by taking advantage of new performance data to ratchet up its performance criteria (Weitzman, 1980). Consider a performance criterion set at period $t$; if a firm performs better this period, the government raises the target for the next period. The manager anticipates the negative externality of current efforts on the future stream of rewards, and reduces current efforts relative to the level of effort that prevailed when the government was commited to repeating the optimal static performance contract. In this example when the government refuses to abide by the optimal static contract for each period, and instead takes advantage of new information, the firm refrains from working at the socially optimal level.

8. A sufficient condition for this assumption to hold is that $\theta$ belongs to the range where $\varphi^{\prime}(\theta) \geq 0$, satisfied for the uniform distribution, and for the lognormal distribution when $\ln (\theta)$ is below its mean. Lognormal distribution is (and normal distribution is not) a relevant distribution in our example because we constraint $\theta$ to be positive, as required by a lognormal distribution. More generally, since most commonly-used density functions usually do not begin to decrease until the random variable hits its median or mean, the assumption is most likely to be satisfied when $\theta$ is below the mean or the median of the random variable.

9. See Appendix B for details of the proof.

${ }^{10}$ There were 17 respondents to the questionnaires, one from each of the sample companies and monitoring agencies, with the exception of the Mexican Government which did not respond. Field interviews were done in Ghana and Senegal by Dyer Cisse (whose interview reports were used for this article), and in India and Korea (during several earlier visits from 1990 to 1994) by one of the authors. Staff from the Philippines government responsible for the contracts were interviewed in Washington, D.C. One of the authors was also involved in the initial discussions of the Mexico contracts.

${ }^{11}$ We included one electricity company from each country to test for industry effects (none were found).

${ }^{12}$ Korea Telecoms was created as a separate company only two years before its contract started. Senegal Telecoms was created in the same year that it signed its first contract; we extrapolated backwards two years, using data from prereorganization telecom units. We included Senegal Electricity's second contract (starting in 1990), even though it was never signed. The conclusions would not change if that period were omitted. We also took 1987 as the start date for India Oil's contracts even thought it signed a pilot form of contract in 1986 (based on the multi-year French contract plan). The government later switched to a very different sort of contract (closer to the Korean model, using yearly weighted targets). The conclusions would not change if the earlier contract period were included.

${ }^{13}$ Performance improvement should not be confused with good performance in some absolute sense. For example, Ghana Water and Sewerage increased TFP by an average of 12.5 percent a year during 
the three years of contracts for which we have data (1990, 1991 and 1992). Yet this is still a company with almost 50 percent of its water unaccounted for and only about two-thirds of the population served with water.

${ }^{14}$ Independent auditors for Senegal Electricity concluded that "the accounting and financial management show such an amount of anomalies and deficiencies that the auditor will not be able to release an opinion on the matter." World Bank, "Senegal: Note on The Institutional Study for the Power Sector", Memo, 1992.

${ }^{15}$ A study of Pakistan (Shirley 1989) found that poor information also led to low powered incentives there.

${ }^{16}$ Other obstacles were unrealistic objectives, poor management, factors outside the management's and government control (such as world markets), failure of international agencies to release funds and public attitudes towards the company. Number of respondents was 17.

${ }^{17}$ Standing boards of directors were replaced by executive boards; government representation on the boards was reduced to two members; only board approval of the budget was required when previously the supervising ministry, the Economic Planning Board and the cabinet also had to approve; responsibility for most personnel decisions was shifted from the supervising ministry to the enterprise; procurement through a centralized office was made voluntary instead of compulsory; all oversight was centered in the contract with one yearly inspection, compared to the extensive system of controls and inspections used before (in one year before the contracts Korea Electricity had eight different inspections lasting 108 days); preference was shifted to internal candidates for senior positions (previously over half of all such appointments were from outside the firm) and an explicit merit assessment was introduced (Shirley 1991, 11-12).

${ }^{18}$ An early opinion survey of 750 employees in all ranks of the SOEs under contract found that 93 percent thought that management had improved, thanks to the performance evaluation system; 55 percent saw substantial improvement; 94 percent of the executive directors said that there had been substantial or significant improvement (Song 1988).

${ }^{19}$ A sign of this waning commitment may be the move away from public profitability, as mentioned earlier.

${ }^{20}$ Mexico Electricity's experience under the contract differs from that of other SOEs in Mexico in that the government followed through on its commitments under the contract. The Mexican government distinguishes between the Financial Restructuring Pact applied to Mexico's Electricity and performance contracts. A World Bank assessment of Mexico's standard performance contracts with five other SOEs concluded that the results were disappointing. The study attributed the poor outcomes to a lack of adequate consultation between government and the SOEs; government attempts to treat the contracts as one more instrument of control among many; and targets which lack coherence, simultaneously overlapping and leaving gaps (World Bank 1992).

${ }^{21}$ Interview with Hafeez Shaikh (1994).

22 In Ghana, government negotiators and monitors in the State Enterprises Commission (SEC) lost power when responsibility for energy contracts was shifted to the sector agencies. Although the shift only affected two SOEs directly (including one of the three in our sample), staff in the SEC believe that the change adversely affected the credibility of all monitoring and negotiating. According to an SEC report "This situation tends to create considerable uncertainty about who can require performance information from the SOEs. This has affected the ability of the Commission to perform its reporting and evaluation function." (SEC 1991).

${ }^{23}$ In Korea, evaluations of how different departments, divisions and offices contributed to contract achievements are taken into account in internal promotions (Shirley 1991).

${ }^{24}$ Field interviews. 
${ }^{25}$ In addition Philippines Electricity's targets for new lines, main lines, income, rate of regurn on revalued assets and power generation per employee were reduced even though the company had exceeded the target the previous year. Delays in getting information on achievements may be a reason why government agents agreed to set targets well below the previous year's achievements.

${ }^{26}$ Public profits are private profits adjusted to measure returns to society as a whole and to exclude factors beyond the control of managers (Jones 1991).

${ }^{27}$ See Jones (1993) for more on the concepts of criterion and criterion values and an excellent review of the issues of performance contracting.

${ }^{28}$ Interviews with government evaluators and knowledgeable observers also suggest that the managers in our sample negotiated for more and softer targets and were often responsible for changes in the criteria.

${ }^{29}$ Some observers have suggested in discussions of this paper that the weaknesses in the targets are due to a lack of capacity on the part of the government agencies or are part of the early phase of a learning process about how to contract successfully. These explanation do not seem credible to us because numerous or fluctuating targets are found in the entire sample, in countries where government capacity is strong (India, Korea or Mexico) and in countries where the contract process has been in place for more than five years (Korea and Senegal).

${ }^{30}$ The data were taken from enterprise audited accounts and put into comparable formats where necessary. Although every effort was made to verify the accuracy of the data, in some cases the underlying information systems are weak. However, it seems plausible that errors are not correlated over time and do not greatly affect the trend analysis.

${ }^{31}$ Where assets were not revalued by the company, we revalued them, using company figures for depreciation and the GDP deflator for inflation.

${ }^{32}$ Out of a total of 17 respondents to this question.

${ }^{33}$ Some commentators have asked us why we did not judge each firm's performance by its attainment of the economic targets specified in its contract. As mentioned, we did investigate performance against targets and found that all of the sample SOEs achieved at least satisfactory ratings where a score was assigned (Senegal had no such score). However, since many of the targets (as we analyzed above) were subject to manipulation, firms might attain their economic targets under the contract but not necessarily operate more profitably or productively. (For example, 30 percent of India Electricity's score in 1991-92 depended on the volume of electricity they generated; output went up but the use of material inputs rose even faster. India Electricity achieved its target and received a score of excellent that year, but its TFP fell below precontract levels.

${ }^{34}$ Its prices are nevertheless about one-third less than those charged to the private sector, but private producers usually have more freedom to change producer prices.

${ }^{35}$ We also compared performance trends with trends in inflation and interest rates.

${ }^{36}$ This is not likely to work in every potentially competitive sector. Financial enterprises, for example, may still have strong information advantages despite competition because of implicit or explicit safety nets (such as deposit insurance) and the adverse effects of competition on managers' incentives to act prudently. ${ }^{37}$ The authors are currently studying the experience with performance contracts for competitive and monopoly SOEs in China. This study will correct some of these problems, since it will be a much larger sample with controls, and we have both productivity measure and better descriptions of provisions of contracts. Econometric analysis will be used. 
Table 1. Number of Performance Contracts in Developing Countries, by Sector

\begin{tabular}{lcccccc}
\hline & & & Latin & Mid-East and & Central \\
Sector & Africa & Asia & America & North Africa & Europe & Total \\
\hline Transport & 26 & 8 & 4 & 6 & 2 & 46 \\
Telecom and Post & 15 & 2 & 1 & 1 & 0 & 19 \\
Extractive industries & 6 & 26 & 2 & 2 & 3 & 39 \\
Agriculture & 13 & 3 & 2 & 0 & 0 & 18 \\
Water & 4 & 4 & 0 & 1 & 0 & 9 \\
Electricity & 11 & 8 & 6 & 1 & 1 & 27 \\
Other & 61 & 160 & 1 & 1 & 4 & 227 \\
$\quad$ Total & 136 & 211 & 16 & 12 & 10 & 385 a \\
\hline
\end{tabular}

a. Data for Romania only. Contracts are also being used in Bulgaria, but no details are available.

b. Total figures cover thirty-one countries. In addition, Indonesia reports 180 firms, and China 103,000; no breakdown by industry was available. Data reflects situation as of June 1994. Based on a world-wide search using World Bank and other sources. In some countries additional contracts may have been awarded. Source: Survey of World Bank reports and staff.

Table 2. Case Study Enterprises

\begin{tabular}{|c|c|c|c|}
\hline Country (contract type) & Enterprise name: (NAME USED IN TEXT) & Contract duration & $\begin{array}{c}\text { First contract } \\
\text { year }\end{array}$ \\
\hline \multirow[t]{3}{*}{ Ghana (performance contract) } & $\begin{array}{l}\text { Electricity Corporation of Ghana (ECG): } \\
\text { GHANA ELECTRICITY }\end{array}$ & \multirow[t]{3}{*}{ Yearly } & 1989 \\
\hline & $\begin{array}{l}\text { Ghana Water and Sewerage Corporation (GWSC): } \\
\text { GHANA WATER }\end{array}$ & & 1989 \\
\hline & $\begin{array}{l}\text { Ghana Posts and Telecommunications (GP\&T): } \\
\text { GHANA TELECOM }\end{array}$ & & 1990 \\
\hline $\begin{array}{l}\text { India (memorandum of } \\
\text { understanding) }\end{array}$ & $\begin{array}{l}\text { National Thermal Power Corporation (NTPC): } \\
\text { INDIA ELECTRICITY }\end{array}$ & Yearly & 1987 \\
\hline & $\begin{array}{l}\text { Oil and Natural Gas Commission (ONGC): } \\
\text { INDIA OIL }\end{array}$ & (published) & \\
\hline \multirow[t]{2}{*}{$\begin{array}{l}\text { Korea (performance evaluation } \\
\text { and measurement system) }\end{array}$} & $\begin{array}{l}\text { Korea Electric Power Corporation (KEPCO): } \\
\text { KOREA ELECTRICITY }\end{array}$ & \multirow{2}{*}{$\begin{array}{l}\text { List of yearly } \\
\text { targets }\end{array}$} & \multirow[t]{2}{*}{1984} \\
\hline & $\begin{array}{l}\text { Korea Telecommunications Authority (KTA): } \\
\text { KOREA TELECOMS }\end{array}$ & & \\
\hline $\begin{array}{l}\text { Mexico (convenio de } \\
\text { rehabilitacion financiera) }\end{array}$ & $\begin{array}{l}\text { Comision Federal de Electricidad (CFE): } \\
\text { MEXICO ELECTRICITY }\end{array}$ & 3 years & 1986 \\
\hline \multirow[t]{2}{*}{$\begin{array}{l}\text { Philippines (performance moni- } \\
\text { toring and evaluation system) }\end{array}$} & $\begin{array}{l}\text { Metropolitan Water and Sewerage System } \\
\text { (MWSS): PHILIPPINES WATER }\end{array}$ & \multirow{2}{*}{$\begin{array}{l}\text { List of yearly } \\
\text { targets }\end{array}$} & \multirow[t]{2}{*}{1989} \\
\hline & $\begin{array}{l}\text { National Power Corporation (NPC): } \\
\text { PHILIPPINES ELECTRICITY } \\
\end{array}$ & & \\
\hline \multirow[t]{2}{*}{ Senegal (contrat plan) } & $\begin{array}{l}\text { Societe Nationale d' Electricite (SENELEC): } \\
\text { SENEGAL ELECTRICITY }\end{array}$ & \multirow[t]{2}{*}{3 years } & 1987 \\
\hline & $\begin{array}{l}\text { Societe Nationale des Telecommunications du } \\
\text { Senegal (SONATEL): SENEGAL TELECOMS }\end{array}$ & & 1986 \\
\hline
\end{tabular}


Figure 1 Summary of Sample Contracting Problems

\begin{tabular}{|c|c|c|c|c|c|c|c|c|c|c|c|c|c|}
\hline & & \multicolumn{4}{|c|}{ Information and Incentives } & \multicolumn{3}{|c|}{ Government commitment } & \multicolumn{5}{|c|}{ Managerial commitment } \\
\hline & & $\begin{array}{c}\text { Poor } \\
\text { accounting }\end{array}$ & $\begin{array}{c}\text { Unskilled, } \\
\text { unstable } \\
\text { negotiators }\end{array}$ & $\begin{array}{c}\text { Unskilled, } \\
\text { unstable } \\
\text { evaluators }\end{array}$ & $\begin{array}{c}\text { Low } \\
\text { power of } \\
\text { incentives }\end{array}$ & $\begin{array}{c}\text { Lack of } \\
\text { costly } \\
\text { signals } \\
\end{array}$ & Reneging & $\begin{array}{c}\text { No } \\
\text { 3rd party } \\
\text { enforcement }\end{array}$ & $\begin{array}{c}\text { Managerial } \\
\text { bargaining } \\
\text { power }\end{array}$ & $\begin{array}{c}\text { No } \\
\text { performance } \\
\text { impact on } \\
\text { career } \\
\end{array}$ & $\begin{array}{c}\text { Examples } \\
\text { of soft } \\
\text { targets }\end{array}$ & $\begin{array}{c}\text { Numerous } \\
\text { targets } \\
(>20) \\
\end{array}$ & $\begin{array}{l}\text { Fluctuating } \\
\text { targets } \\
\text { (>18\% per } \\
\text { year) }\end{array}$ \\
\hline \multirow[t]{2}{*}{ Ghana } & Electricity & 0 & 0 & 0 & 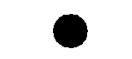 & 0 & 0 & 0 & 0 & 0 & & 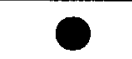 & \\
\hline & Telecoms & 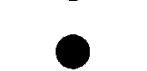 & & 0 & & D & (1) & & & & & & \\
\hline \multirow[t]{2}{*}{ India } & Electricity & 0 & 0 & 0 & 0 & 0 & 0 & 0 & D & 0 & 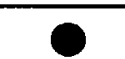 & 0 & \\
\hline & Uni & 0 & (D) & 0 & & 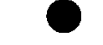 & 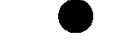 & 0 & D & & & & 0 \\
\hline \multirow[t]{2}{*}{ Korea } & Electricity & 0 & D & 0 & 0 & $\bigcirc$ & 0 & 0 & D & ( & & & 0 \\
\hline & Telecoms & $\bigcirc$ & D & 0 & 0 & 0 & 0 & 0 & D & 0 & & & \\
\hline Mexico & Electricity & 0 & 0 & D & 0 & 0 & 1 & 0 & D & $\mathbf{0}$ & & 0 & 0 \\
\hline \multirow[t]{2}{*}{ Philippines } & Electricity & 0 & & 0 & ? & 0 & 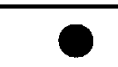 & 0 & ? & 0 & 0 & 0 & 0 \\
\hline & Water & 0 & & & & & & & & & & 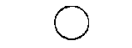 & \\
\hline \multirow[t]{2}{*}{ Senegal } & Electricity & 0 & 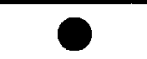 & 0 & 0 & 0 & 0 & 0 & 0 & 0 & 0 & 0 & 0 \\
\hline & Telecoms & & & & & & & & & & & & 0 \\
\hline
\end{tabular}

$=$ Major problem

$\mathrm{D}=$ Somewhat of a problem

$\mathrm{O}=$ Little or no problem 
Figure 2. Pre- and Postcontract Performance: Net Rate of Return on Revalued Assets

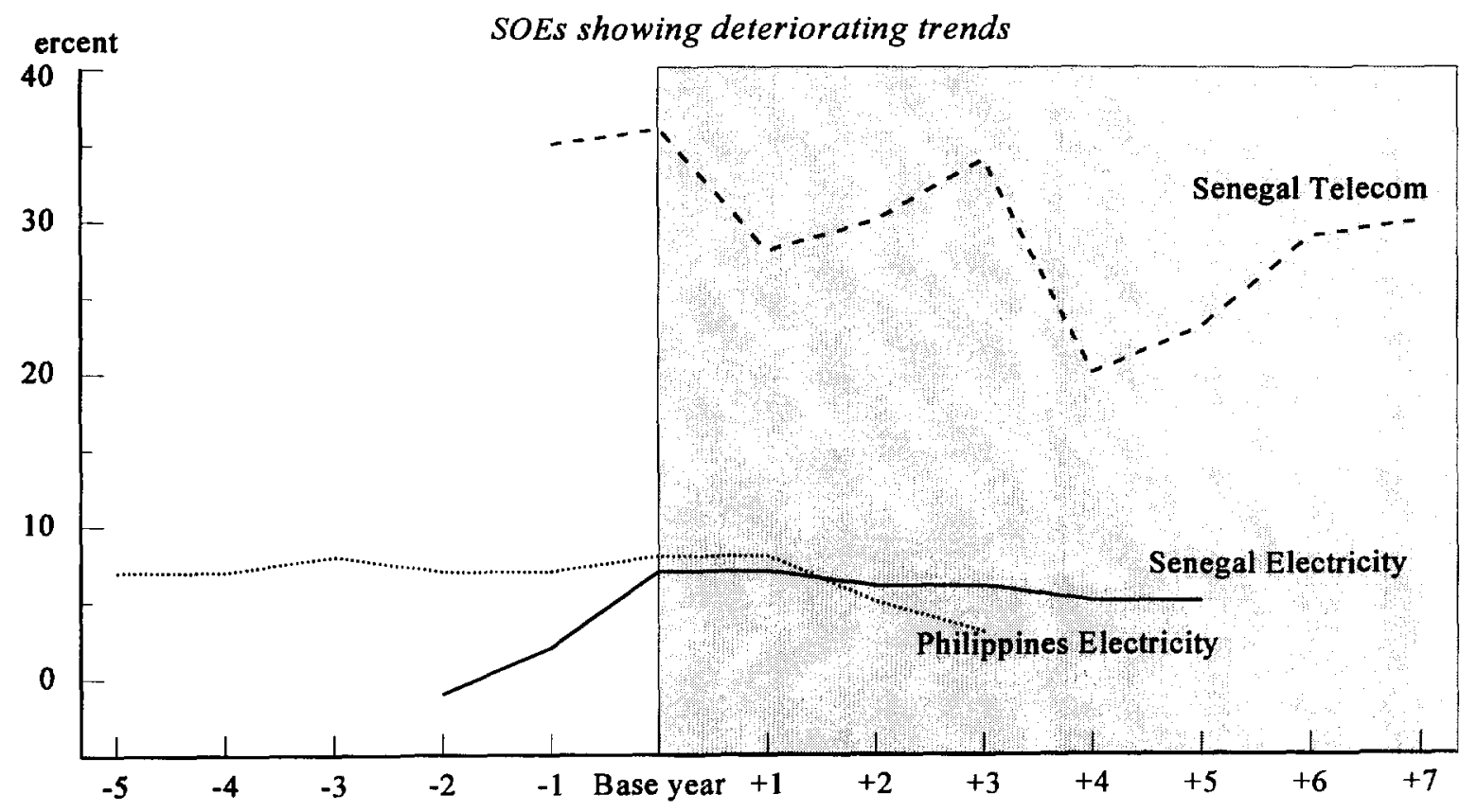

Source: Company data and World Bank estimates.

Figure 3. Pre- and Postcontract Performance: Labor (indexed to base year)

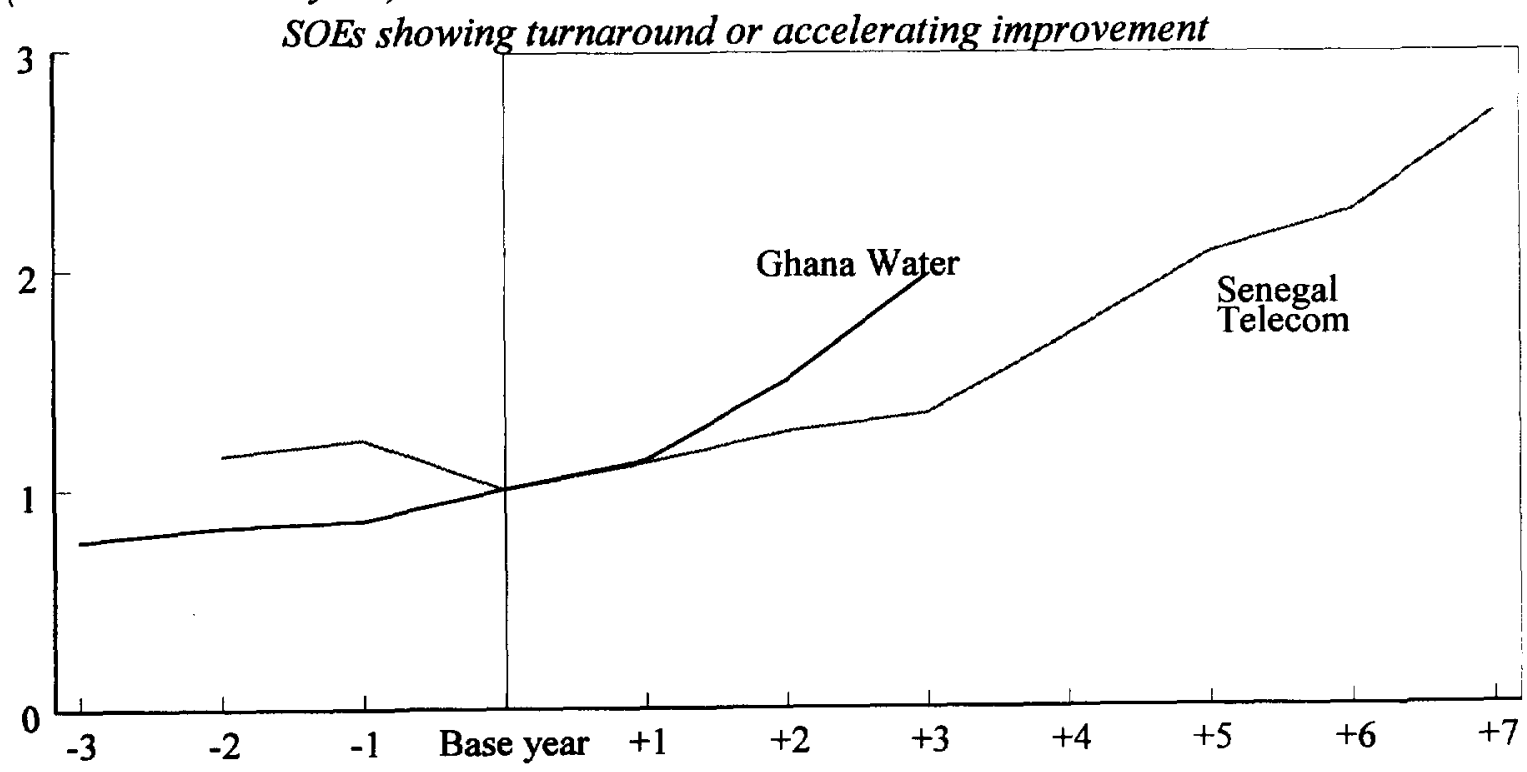


Figure 4. Pre- and Postcontract Performance: Total Factor (indexed to base year)
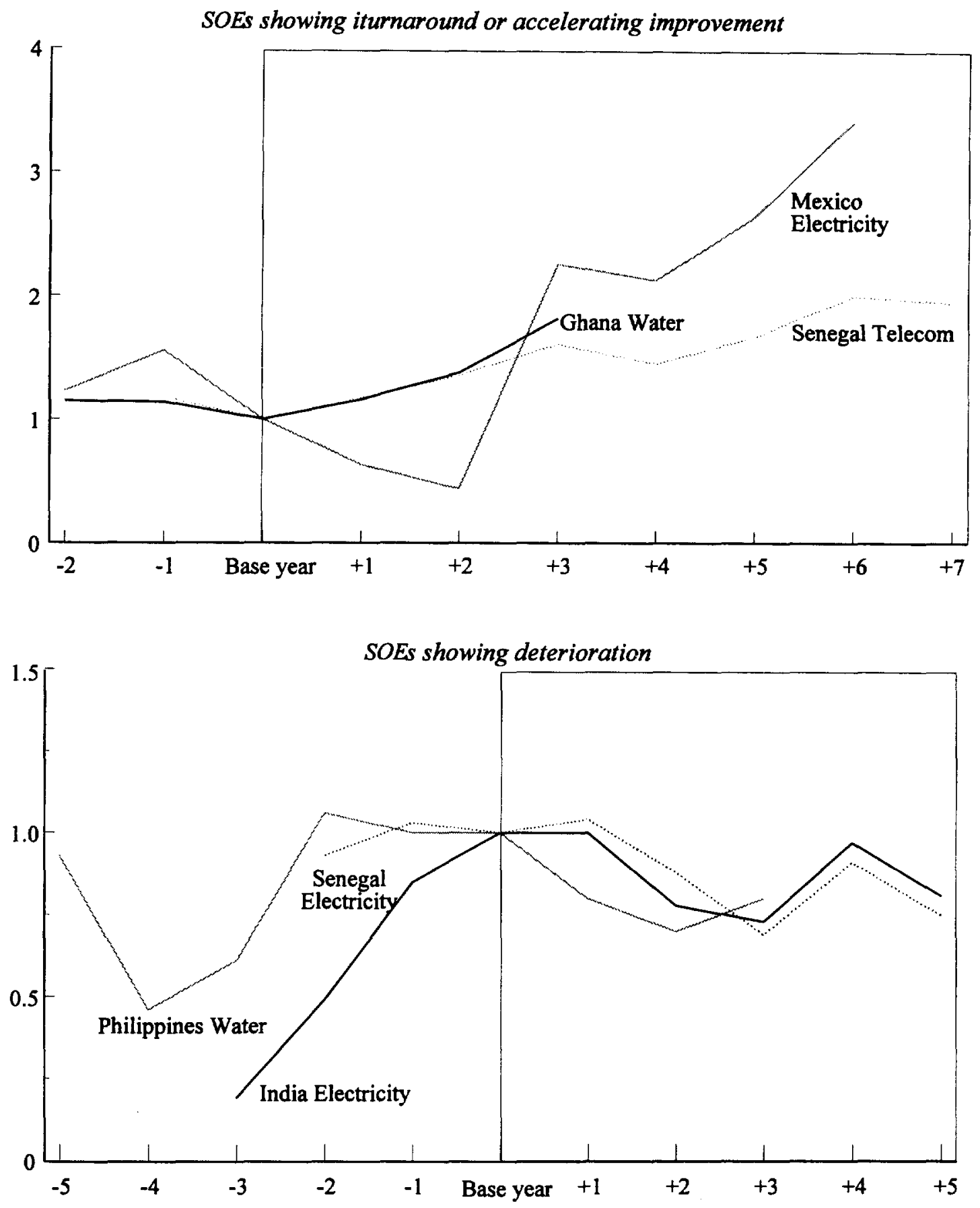

Source: Company data and World Bank estimates. 
Figure 5. Performance Changes after the Introduction of Performance Contract

Number of state-owned enterprises

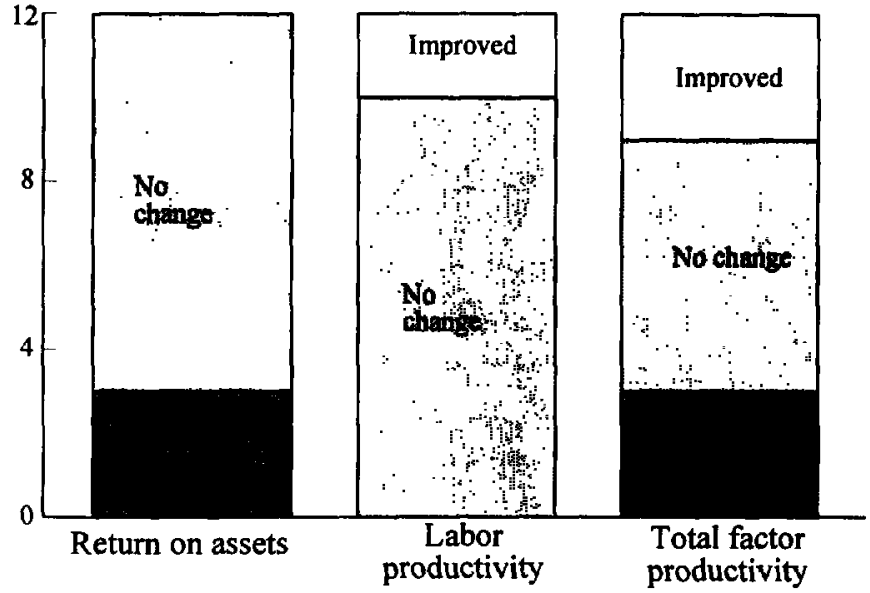

Source: Comapany data and World Bank estimates. 
Figure 6 Summary of Contract Outcomes

\begin{tabular}{rr|c|c|c|}
\multirow{2}{*}{} & & \multicolumn{3}{|c|}{ Changes in Trend in: } \\
\cline { 3 - 5 } & & ROA & LP & TFP \\
\hline Ghana & Electricity & 0 & 0 & 0 \\
& Water & 0 & + & + \\
& Telecoms & 0 & 0 & 0 \\
\hline India & Electricity & 0 & 0 & - \\
& Oil & 0 & 0 & 0 \\
\hline Korea & Electricity & 0 & 0 & 0 \\
& Telecoms & 0 & 0 & 0 \\
\hline Mexico & Electricity & 0 & 0 & + \\
\hline Philippines & Electricity & - & 0 & 0 \\
& Water & 0 & 0 & - \\
\hline Senegal & Electricity & - & 0 & - \\
& Telecoms & - & + & + \\
\hline
\end{tabular}

$$
\begin{aligned}
& 0=\text { No change in trend } \\
& +=\text { Trend improved } \\
& -=\text { Trend deteriorated }
\end{aligned}
$$


Title WPS1746 The Role of Long-Term Finance:
Theory and Evidence

WPS1747 Protection and Trade in Services: A Survey
Author

Gerard Caprio, Jr.

Asli Demirgüç-Kunt

Bernard Hoekman

Carlos A. Primo Braga

WPS1748 Has Agricultural Trade Liberalization Merlinda D. Ingco Improved Welfare in the Least-Developed

Countries? Yes

WPS1749 Applying Economic Analysis to Technical Assistance Projects

WPS1750 Regional Integration and Foreign Direct Investment: A Conceptual Framework and Three Cases

WPS1751 Using Tariff Indices to Evaluate Preferential Trading Arrangements: An Application to Chile

WPS1752 Ghana's Labor Market (1987-92)

WPS1753 Can Capital Markets Create Incentives for Pollution Control?

WPS1754 Research on Land Markets in South Asia: What Have We Learned?

WPS1755 Survey Responses from Women Workers in Indonesia's Textile, Garment, and Footwear Industries

WPS1756 World Crude Oil Resources: Evidence from Estimating Supply Functions for 41 Countries

WPS1757 Using Economic Policy to Improve Environmental protection in Pakistan

WPS1758 The Restructuring of Large Firms in Slovakia

WPS1759 Institutional Obstacles to Doing Business: Region-by-Region Results from a Worldwide Survey of the Private Sector
Gary McMahon

Magnus Blömstrom

Ari Kokko

Eric Bond

April 1997

Sudharshan Canagarajah

Saji Thomas

Paul Lanoie

Benoît Laplante

Rashid Faruqee

Kevin Carey

Mari Pangestu

Medelina K. Hendytio

G. C. Watkins

Shane Streifel

Rashid Faruqee

Simeon Djankov

Gernard Pohl

Aymo Brunetti

Gregory Kisunko

Beatrice Weder

April 1997

April 1997

April 1997

April 1997

April 1997

April 1997

April 1997

April 1997

April 1997

April 1997
Date

April 1997

April 1997

April 1997

Contact

for paper

P. Sintim-Aboagye 38526

J. Ngaine

37947

J. Ngaine

37947

C. Bernardo

37699

J. Ngaine 37947

J. Ngaine 37947

B. Casely-Hayford 34672

R. Yazigi

37176

C. Anbiah

81275

J. Israel

85117

J. Jacobson 33710

C. Anbiah

81275

F. Hatab 35835
M. Geller 31393 
Policy Research Working Paper Series

Title

WPS1760 Credibiity of Rules and Economic
Growth: Evidence from a Worldwide
Survey of the Private Sector
WPS1761 Bending the Rules: Discretionary
Pollution Control in China

WPS1762 Strategies for Pricing Publicly Provided Health Services
Author

Ayrno Brumetti

Gregory Kisuniko

Beatrice Weder

Susmita Dasgupta

Mainul Huq

David Wheeler

Paul J. Gertler

Jeffrey $S$. Hammer

WPS1763 China and the Multilaterai investment Guarantee Agency

WPS1764 A Reversal of Fortune for Korean Women: Explaining 1983's Upward Turn in Relative Earnings

WPS1765 Explaining Agricultural and Agrarian Policies in Developing Countries

WPS1766 New Systems ror Old Age Security: Theory, Practice, and Empirical Evidence

WPS1767 Pension Reform: is There a Tradeoff between Efficiency and Equity?

WPS1768 is There a Quantity-Quality Tradeoff as Enrollments increase? Evidence from Tamil Nadu, India

WPS1769 Information, Incentives, and Cornmitment: An Empirical Analysis of Contracts between Government and State Enterprises

WPS1770 Poverty and Social Transfers in Hungary Rodgers Klaus Deininger

Estelle James

P. Duraisamy

Estelle James

Julia Lane

Jee-Peng Tan

Mary M. Shirley

L. Colin Xu
Date

April 1997

Contact for paper

M. Geller 31393

May 1997

May 1997

C. Bernardo 31148

May 1997

E. Beers 36175

Yaba vab der Neykeb

May 1997

Hans $P$. Binswanger

May 1997

D. Housden 36637

May 1997

S. Khan 33651

May 1997

S. Khan 33651

May 1997

S. Khan

May 1997

P. Sintim-Aboagye 38526

Christiaan Grootaert

May 1997

G. Ochieng 31123 